\title{
New alternative to antidotes for novel oral anticoagulants and ticagrelor in the case of severe bleeding
}

\author{
Patrick M. Honore*, Christina David, Rachid Attou, Sebastien Redant, Andrea Gallerani and David De Bels
}

Kuramatsu et al. reviewed current therapies for reversal of new oral anticoagulants (NOACs) and anti-platelet agents in patients with acute intracerebral hemorrhage [1]. In their comments on "Unspecific reversal approaches," we believe that the authors have overlooked another new way to reverse this anticoagulation, especially with NOACs such as rivaroxaban and dabigatran and the new antiplatelet drug, ticagrelor [2]. In the case of severe intoxication with these NOACs or new anti-platelet agents, there is a promising new therapy based upon the use of the CytoSorb device [2]. CytoSorb can very efficiently remove NOACS and anti-platelets agents in order to restore normal coagulation and platelet function and to stop bleeding wherever it is occurring [2]. In their study, Angheloiu et al. were able to remove $99 \%$ of ticagrelor from human blood in less than $4 \mathrm{~h}$ when using CytoSorb [2]. They concluded that CytoSorb can remove representative molecules from two classes of agents-antiplatelet and anticoagulant-and in the future could complement the use of a newly developed specific monoclonal antibody reversal agent for ticagrelor, which is still in the pre-clinical phase and not yet available at the bedside [3]. In other experimental work by Koertge et al. [4], it was found that more than $91 \%$ of rivaroxaban could be removed from the blood during $1 \mathrm{~h}$ of use of CytoSorb [4]. This new therapy could perhaps complement the use of the antidote andexanet alfa [1], particularly if the antidote is not immediately available [4]. Lastly, Hassan et al. reported the intra-operative use of CytoSorb adsorption of ticagrelor and rivaroxaban in emergency openheart surgery [5]. They concluded that this strategy is a safe and effective method to reduce bleeding complications induced by ticagrelor and rivaroxaban in that setting [5]. Studies comparing the two strategies (sorbents versus monoclonal antibodies) are urgently needed.

\footnotetext{
* Correspondence: Patrick.Honore@CHU-Brugmann.be

This comment refers to the article available at https://doi.org/10.1186/ s13054-019-2492-8.

ICU Department, Centre Hospitalier Universitaire Brugmann-Brugmann University Hospital, Place Van Gehuchtenplein, 4, 1020 Brussels, Belgium
}

\author{
Abbreviation \\ NOACs: New oral anticoagulants
}

\author{
Acknowledgements \\ None.
}

\section{Authors' contributions}

$\mathrm{PMH}, \mathrm{SR}$ and DDB designed the paper. All authors participated in drafting the manuscript. All authors have read and approved the final version.

\section{Funding}

None.

Availability of data and materials

Not applicable.

\section{Ethics approval and consent to participate \\ Not applicable.}

\section{Consent for publication}

Not applicable.

\section{Competing interests}

The authors declare that they have no competing interests.

Received: 20 January 2020 Accepted: 5 February 2020

Published online: 11 February 2020

\section{References}

1. Kuramatsu JB, Sembill JA, Huttner HB. Reversal of oral anticoagulation in patients with acute intracerebral hemorrhage. Crit Care. 2019;23(1): 206. https://doi.org/10.1186/s13054-019-2492-8 Review.

2. Angheloiu GO, Gugiu GB, Ruse C, Pandey R, Dasari RR, Whatling C. Ticagrelor removal from human blood. JACC Basic Transl Sci. 2017;2(2):13545. https://doi.org/10.1016/j.jacbts.2017.01.007 eCollection 2017 Apr.

3. Willeman T, Marlu R, Böhle H, Francony G, Jourdil JF, Fonrose X, et al. Lethal cerebral hemorrhage after ticagrelor intoxication: a specific antidote is urgently needed. Clin Toxicol (Phila). 2018;56(12):1200-3. https://doi.org/10. 1080/15563650.2018.1480026 Epub 2018 Jun 11.

4. Koertge A, Wasserkort R, Wild T, Mitzner S. Extracorporeal hemoperfusion as a potential therapeutic option for critical accumulation of rivaroxaban. Blood Purif. 2018;45(1-3):126-8. https://doi. org/10.1159/000484923 Epub 2017 Dec 21.

5. Hassan K, Kannmacher J, Wohlmuth P, Budde U, Schmoeckel M, Geidel S. Cytosorb adsorption during emergency cardiac operations in patients at high risk of bleeding. Ann Thorac Surg. 2019. https://doi. org/10.1016/j.athoracsur.2018.12.032 [Epub ahead of print].

\section{Publisher's Note}

Springer Nature remains neutral with regard to jurisdictional claims in published maps and institutional affiliations. 